\title{
Listy Włodzimierza Zajączkowskiego do Hadży Seraji Szapszała
}

\author{
Maria Emilia Zajączkowska-Łopatto
}

Związek Karaimów Polskich

\section{Włodzimierz Zajączkowski’s letters to Seraya Shapshal}

Summary: Włodzimierz Zajączkowski (1914-1982), who prior to WWII was a graduate student in the Chair of the Muslim East at the Jagiellonian University, returned in the autumn of 1946 to Cracow in order to continue his studies and complete his Ph.D. thesis on the Gagauz Turks. He exchanged letters with Seraya Shapshal (1873-1961), the spiritual leader of the Karaims and an Orientalist, who was one of his mentors both in life and in his academic career. These letters, written in Russian in the years 1947-1958, are at present stored in the Wróblewski Library of the Lithuanian Academy of Science in Vilnius. They are published in a Polish translation together with a short biographical and bibliographical essay.

The letters concerned the restoration and development of Oriental Studies in Cracow, Warsaw and Wrocław. W. Zajączkowski informed S. Shapshal on scholarly events in Poland, the progress he was making in his own studies, as well as the materials he was going to publish. He consulted Shapshal, a native speaker of Crimean Karaim and a specialist in Crimean Karaim popular literature, on linguistic issues. He also asked for help in obtaining foreign publications not available in Poland, especially those published in U.S.S.R., and sent Shapshal Polish books and scientific journals. We also find in the letters some information on the social life of the Karaims in Poland and W. Zajaczkowski's contacts with family and friends.

Keywords: Włodzimierz Zajączkowski, Seraya Shapshal, Turkish studies, Oriental studies, Karaims 
W Dziale Rękopisów w Bibliotece Wróblewskich Litewskiej Akademii Nauk w Wilnie (Lietuvos Mokslų Akademijos Vrublevskių Biblioteka) w Wilnie w zbiorze F-143, pod nr 718 przechowywana jest korespondencja Włodzimierza Zajączkowskiego do Hadży Seraji Szapszała. Składa się na nią 10 listów napisanych w Krakowie w latach 1947-1958 oraz jedna kartka pocztowa wysłana z Warny.

Listy te, pisane w języku rosyjskim, zostały przeze mnie przetłumaczone na język polski. Wyłania się z nich obraz powojennej odbudowy i rozwoju orientalistyki w Krakowie, Warszawie i Wrocławiu. W. Zajączkowski bardzo dokładnie opisuje w nich nowe wydawnictwa, prosi o przesłanie nowych publikacji uczonych radzieckich, niedostępnych w końcu lat czterdziestych na rynku polskim. Stara się być poinformowanym, pomaga innym zaspokoić ich głód książek, opisuje zniszczenia wojenne w księgozbiorach zarówno prywatnych, jak i uniwersyteckich.

Postać adresata, hachana Hadży Seraji Szapszała, została już szczegółowo omówiona przy okazji publikacji skierowanej do niego korespondencji Ananiasza Zajączkowskiego, stąd w tym krótkim wstępie do listów skoncentruję się na osobie ich nadawcy.

Autor listów to przyszły profesor Uniwersytetu Jagiellońskiego, turkolog, badacz folkloru Gagauzów i innych ludów tureckich, w owym czasie świeży „repatriant”, próbujący z pomocą swego dawnego profesora i mentora odnaleźć się w nowej rzeczywistości. Koleje jego życia, w których nie brakowało dramatycznych zdarzeń, podobne były do losów wielu innych przedstawicieli tego pokolenia. Włodzimierz Zajączkowski przyszedł na świat 21 lipca $1914 \mathrm{r}$. w Wilnie jako pierworodny syn Józefa Awii (1884-1966) i Nadziei ze Szpakowskich (1894-1945), w szanowanej, tradycyjnej rodzinie Karaimów trockich.

W 1933 r. ukończył Państwowe Gimnazjum im. Króla Zygmunta Augusta i postanowił, zgodnie ze swoimi zainteresowaniami i za zgodą ojca, prezesa gminy karaimskiej w Trokach (1929-1931), złożyć dokumenty na studia na Wydziale Filozoficznym Uniwersytetu Jagiellońskiego, w Katedrze Wschodu Muzułmańskiego, kierowanej przez profesora dr Tadeusza Kowalskiego. Poszedł w ten sposób w ślady Ananiasza Zajączkowskiego², również ucznia Kowalskiego,

1 W tym miejscu pragnę podziękować Panu Dyrektorowi Sigitasovi Narbutasovi i pracownikom Biblioteki za okazaną mi życzliwość i pomoc oraz wyrażenie zgody na opublikowanie tej korespondencji tak ważnej dla opracowania naukowej spuścizny W. Zajączkowskiego.

2 Ananiasz Zajączkowski i ojciec Włodzimierza, Józef Awia, byli stryjecznymi braćmi. 
a w owym czasie kierownika Seminarium Turkologicznego w nowo powstałym Instytucie Orientalistycznym Uniwersytetu Warszawskiego³. „Dokumenty Włodzimierza Zajączkowskiego odesłałem do Krakowa. Prof. Kowalski obiecał zająć się jak najżyczliwiej” - pisze A. Zajączkowski z Warszawy do Seraji Szapszała w Wilnie w liście datowanym 17 września 1933 r. ${ }^{4}$

Już w 1936 r., czyli na rok przed uzyskaniem magisterium, W. Zajączkowski zostaje zatrudniony w macierzystej katedrze jako asystent. W ten sposób staje się urzędnikiem państwowym, co będzie miało wpływ na jego dalsze losy. Jednocześnie studiuje także historię i w rok po uzyskaniu magisterium z turkologii na podstawie pracy „Zapożyczenia arabskie i perskie w języku zachodniokaraimskim" otrzymuje na Wydziale Historycznym drugi tytuł magistra, składając pracę pod tytułem "Chan tatarski Krym Girej i Polska”. Jeszcze przed wybuchem wojny za radą profesora Kowalskiego zaczyna zbierać materiały do pracy doktorskiej, która ma być poświęcona Gagauzom, żyjącej na Bałkanach grupie etnicznej pochodzenia tureckiego.

Wybuch II wojny światowej zastał go w Wilnie. „Włodek - jak Pan Profesor zresztą już wie - ma dobrą posadę w gimnazjum (ok. 500 litów miesięcznie)." informował A. Zajączkowski T. Kowalskiego w liście datowanym 29 września 1940 r. ${ }^{5}$ Podjął pracę jako nauczyciel historii w szkole średniej ${ }^{6}$. W 1944 r. pracował w III Gimnazjum Męskim w Wilnie z polskim językiem wykładowym7

W czasie wojny zacieśniły się jego kontakty z Hadży Serają Szapszałem (18731961), hachanem karaimskim i uznanym orientalistą. Możemy przypuszczać, że

3 J. Tyszkiewicz, Początki seminarium turkologicznego prof. Ananiasza Zająckowskiego: 1933-1936, „Almanach Karaimski” 2014, nr 3, s. 107-11; T. Majda, Ananiasz Zajaczkowski 1903-1970, [w:] Baraniewski W., Tygielski W., Wróblewski A. K. (red.), Portrety Uczonych. Profesorowie Uniwersytetu Warszawskiego po 1945, Warszawa 2016, s. 536-547.

4 Listy Ananiasza Zajaczkowskiego do Seraji Szapszała, „Almanach Karaimski” 2013, nr 2, list nr 31, s. 120. Zob. też M. Pawelec, Listy do Wilna. Seraja Szapszal jako korespondent Ananiasza Zajaczkowskiego, tamże, s. 19-36; U. Wróblewska, Działalność kulturalno-oświatowa Karaimów w Drugiej Rzeczypospolitej, Białystok 2015, s. 103 -104, 107.

5 T. Majda (red.), Urzeczeni Orientem. Listy Ananiasza Zajaczkowskiego do Tadeusza Kowalskiego, Warszawa 2013, s. 115.

6 Na łamach miejscowej gazety opublikował notatkę o akcji edukacyjnej wśród nauczycieli szkoły, w której pracował: Praca kulturalna $w$ VIII szkole średniej, „Prawda Wileńska”, wydanie z 31 I 1941, s. 5 (BLAN F143-1599).

7 „Prawda Wileńska”, wydanie z 15 X 1944, s. 4. 
w gronie słuchaczy wykładów na temat dziejów Karaimów, wygłaszanych przez S. Szapszała na przełomie lat 1941 i $1942^{8}$ znajdował się także W. Zajączkowski.

6 grudnia 1944 r. W. Zajączkowski został aresztowany przez NKWD Litewskiej SSR. Warto w tym miejscu wspomnieć, że wkrótce potem podobny los spotkał jego młodszego brata, Romualda oraz Izaaka Zajączkowskiego (1889-1945), adwokata, przed wojną prezesa gminy karaimskiej w Wilnie9.

W celu przeprowadzenia dalszych przesłuchań W. Zajączkowski został przekazany do łagru ludowego komisariatu spraw wewnętrznych ZSRR. 23 listopada 1945 r. trafił do Workutłagu (Воркутлаг, Воркутинский исправительнотрудовойлагерь) ${ }^{10}$. W sprawie karnej o sygnaturze P-4522 został 9 kwietnia 1946 r. oskarżony o to, że aresztowany przez gestapo w lutym 1942 r. pod zarzutem sprzyjania sowietom, zeznawał o znanych sobie komunistach i został zwerbowany do współpracy pod pseudonimem „Z”, co stanowiło przestępstwo określone w artykule 58-1a ${ }^{11}$ kodeksu karnego RFSRR.

Już w lutym 1946 r., na wieść o aresztowaniu profesor Kowalski wraz z Ananiaszem Zajączkowskim rozpoczęli akcję ratunkową, starając się zdobyć dla W. Zajączkowskiego przydział repatriacyjny, aby sprowadzić go do Polski. Interweniowali w Ministerstwie Spraw Zagranicznych, w biurze do spraw repatriacji ${ }^{12}$.

5 kwietnia 1946 r. zapadła decyzja o zwolnieniu W. Zajączkowskiego z braku dowodów przestępstwa, zatwierdzona w dniu 9 kwietnia 1946 r. przez Archangielski Oddział Ministerstwa Spraw Wewnętrznych ${ }^{13}$. „O Włodzimierzu Z[ajączkowskim] miałem wiadomość od osoby, kt[óra] przyjechała z Wil[na]. Napisał do ojca, że wraca «czwartym transportem». Ojciec więc czeka na niego,

8 Urzeczeni Orientem, op. cit. s. 175; S. Pilecki, Chłopiec z Leśnik. Dziennik lat 1939-1945, Wrocław 2009, s. 183; tenże Karaimskie życie rodzinne, społeczne i religijne okresu międzywojennego, [w:] B. Machul-Telus (red.), Karaimi, Warszawa 2012, s. 47.

9 S. Pilecki, op. cit. s. 356. O Izaaku Zajączkowskim zob. też M. E. Zajączkowska-Łopatto, Obowiązek i ofiara. Życie i działalność mecenasa Izaaka Zajaczkowskiego, „Awazymyz” 2015, nr 1 (46), s. 4-8.

10 Informacja z Litewskiego Archiwum Specjalnego (Lietuvos Ypatingasis Archyvas) z 5 września 2005 r., archiwum prywatne Tamary Firkowicz-Zajączkowskiej, Wilno.

11 Artykuł 58 kodeksu karnego Rosyjskiej Federacyjnej Socjalistycznej Republiki Radzieckiej, który wszedł w życie 25 lutego 1927 r., składał się z 14 paragrafów. Pierwszy z nich, definiujący działalność kontrrewolucyjną, został 8 czerwca 1934 r. uzupełniony o listę punktów precyzujących rozumienie paragrafu. Punkt 1a dotyczył zdrady ZSRR, za co przewidywano karę śmierci przez rozstrzelanie lub karę 10 lat więzienia oraz w obu wypadkach konfiskatę majątku.

12 Urzeczeni Orientem, op. cit., s. 218.

13 Informacja z Litewskiego Archiwum Specjalnego, op. cit. 
potem mają razem przyjechać do kraju."14 - pisał do Kowalskiego A. Zajączkowski 1 sierpnia 1946 r. Niedługo potem W. Zajączkowski zawiadomił telegraficznie Kowalskiego, że pod koniec sierpnia przyjedzie wreszcie do Krakowa ${ }^{15}$.

Dzięki poparciu Kowalskiego, podówczas sekretarza generalnego Polskiej Akademii Umiejętności, znalazł początkowo zatrudnienie w Akademii na stanowisku urzędniczym. Jednocześnie pracował naukowo, starając się nadrobić czas stracony przez wojnę. Zajmował się tematyką karaimską: ekscerpował materiał do słownika języka karaimskiego, którego wydanie planował Kowalski, publikował biografie, artykuły leksykograficzne, recenzje prac na temat historii Turcji. Uważny obserwator ruchu wydawniczego, szczególną uwagę poświęcał bibliografii.

Jednocześnie kontynuował przerwaną przez wybuch wojny pracę nad rozprawą doktorską „Turcy-Gagauzowie - historia, język, etnografia”. Śmierć Kowalskiego 5 maja 1948 r. stanowiła dlań ciężki cios, nie przerwała jednak jego kariery naukowej. W czerwcu 1949 r. uzyskał stopień doktora, a w listopadzie tegoż roku został zatrudniony na etacie starszego asystenta w Katedrze Filologii Orientalnej UJ. W 1953 r. uzyskał stopień adiunkta, a po dwóch latach - docenta. Nominację na profesora nadzwyczajnego otrzymał w 1969 r., a zwyczajnego - 22 X 1980 r. Od 1973 r. do śmierci w 1982 r. kierował Zakładem Turkologii w Instytucie Filologii Orientalnej UJ.

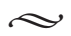

Listy obejmują okres od lutego 1947 (kilka miesięcy po przyjeździe W. Zajączkowskiego do Krakowa) do jesieni 1958 r., z kilkuletnią przerwąa ${ }^{16}$ Wydaje się, że bezpośredni asumpt do rozpoczęcia wymiany korespondencji dała sprawa uznania przez władze radzieckie stopnia doktorskiego uzyskanego przez S. Szapszała przed wojną na Wydziale Filozoficznym Uniwersytetu Jana Kazimierza we Lwowie. S. Szapszał był absolwentem Uniwersytetu Petersburskiego, gdzie po ukończeniu studiów w 1899 r. został zatrudniony jako asystent w katedrze literatury tureckiej Instytutu Języków Wschodnich, a następnie wysłany do Persji dla badań nad językiem perskim i azerskim, lecz poświęcił się karierze dyplomatycznej. W latach 1909-1918 był lektorem języka tureckiego na Uniwersytecie

$14 \quad$ Urzeczeni Orientem, op. cit. s. 215.

15 E. Tryjarski, Restoration of Oriental Studies in Poland after the World War II as Reflected in Five Letters by Tadeusz Kowalski, „Studia Turcologica Cracoviensia” 1998, nr 5, Kraków, s. 280.

16 W. Zajączkowski, jak tylko podróże prywatne do ZSRR stały się możliwe, pojechał w 1955 r. do Wilna, aby spotkać się ze swoim ojcem oraz S. Szapszałem. 
w Petersburgu i opublikował kilka prac naukowych, stopień doktora uzyskał jednak dopiero po przyjeździe do Polski w 1930 r., gdy przyznano mu go na podstawie pracy Kırım Karai Türkleri, wydanej w Stambule w 1928 r. Po wojnie znalazł się w trudnej sytuacji materialnej i podejmował próby znalezienia zatrudnienia jako pracownik naukowy, co dałoby mu z jednej strony źródło utrzymania, z drugiej zaś zapewniło możność zajmowania się problematyką karaimską i swoją własną kolekcją orientaliów i caraimików, przejętą przez władze sowieckie. O pomoc w uzyskaniu stosownego potwierdzenia od osób, które mogłyby zaświadczyć fakt posiadania przezeń stopnia doktora, S. Szapszał poprosił W. Zajączkowskiego, a ten zwrócił się do M. Lewickiego i takie zaświadczenie uzyskał (list nr 1). Co ciekawe, obawiał się zwrócić do T. Kowalskiego ze względu na jego „skrupulatność”. Z listu nr 4 dowiadujemy się jednak, że także prof. Kowalski wystawił zaświadczenie. Ostatecznie dokument dotarł do Wilna (list nr 2) i na tej podstawie Szapszał został zatrudniony w Instytucie Historii i Prawa Akademii Nauk Litewskiej SSR jako młodszy pracownik naukowy. Dopiero po weryfikacji w Głównej Komisji Kwalifikacyjnej dla Pracowników Nauki w Moskwie w 1955 r. otrzymał stopień doktora nauk (odpowiednik doktora habilitowanego) i stanowisko starszego pracownika naukowego ${ }^{17}$.

Pozostałe listy nie odnoszą się już do spraw dotyczących Szapszała, lecz do działalności naukowej W. Zajączkowskiego i życia orientalistycznego w Polsce. W. Zajączkowski informuje o sytuacji polskiej orientalistyki w pierwszych powojennych latach: o przyjazdach uczonych ze Lwowa: prof. Jerzego Kuryłowicza, dr Mariana Lewickiego, powrocie z wojny dr Tadeusza Lewickiego, o kolejnych zjazdach Polskiego Towarzystwa Orientalistycznego i Jubileuszu Polskiej Akademii Umiejętności, o zmianach kadrowych, które nastąpiły po wielkiej stracie, jaką poniosła orientalistyka z powodu zgonu prof. Tadeusza Kowalskiego.

Ważne miejsce w korespondencji zajmują kwestie uzyskania dostępu do publikacji. Wyłania się z nich obraz trudności, na jakie napotykali pracownicy polskiej nauki w tym względzie, i ich prób z jednej strony zdobycia nowych wydawnictw oraz uzupełnienia utraconych wskutek wojny zbiorów z drugiej. Malowniczym przykładem tych zabiegów są pertraktacje w sprawie wymiany publikacji z radzieckim turkologiem, prof. Gordlewskim (listy nr 6, 7, 8). Listy W. Zajączkowskiego do S. Szapszała stanowią cenne źródło informacji o pierwszych latach

17 M. Pawelec, Seraja Szapszal i jego wkład w polska orientalistykę, „Awazymyz” 2012, nr 1 (34), s. 5; tegoż, Niezapomniane spotkania, tamże, s. 9-10; A. Niekricz, Mądrość i dobro świata, tamże, s. 14-15; M. Pawelec, Listy do Wilna. Seraja Szapszał jako korespondent Ananiasza Zajaczkowskiego, „Almanach Karaimski” 2013, nr 2, s. 30-31. 
odbudowy polskiej orientalistyki, jak też o zainteresowaniach naukowych krakowskiego turkologa, szczególnie w zakresie karaimoznawstwa.

Znajdujemy w nich także informacje o powojennym życiu rodzinnym i społecznym Karaimów - przesiedleńców ze swoich historycznych siedlisk w Trokach, Wilnie, Haliczu i Łucku. Są one dość ogólnikowe, wiele z nich jest przekazywanych nie wprost. Nie ma w tym nic niezwykłego, gdy uświadomimy sobie, w jakich czasach listy zostały napisane. W. Zajączkowski nie opisuje więc dokładnie podejmowanych przez A. Zajączkowskiego starań o reaktywowanie Karaimskiego Związku Religijnego i zaznacza jedynie istnienie innego poglądu na formę tej reaktywacji, którego orędownikiem był R. Abkowicz (list nr 4). Przedwojenny hazzan w Łucku i Wilnie nie rozumial, czy też nie chciał zrozumieć, że pojałtański porządek prawny w Polsce nie przewidywał życia religijnego. A. Zajączkowski dążył do jak najszybszego wznowienia działalności KZR jako organu reprezentującego ludność karaimską zamieszkałą w Polsce, żywiąc jednocześnie wciąż nadzieję na przyjazd S. Szapszała. Nie znajdowało to zrozumienia u R. Abkowicza, który uważał siebie za p.o. hachana do czasu przyjazdu Szapszała do Polski i nie przyjmował do wiadomości faktu, że odtworzenie KZR na wzór przedwojenny jest niemożliwe zarówno ze względów formalnych, jak i przede wszystkim politycznych. Ostatecznie akceptację dla działalności społeczno-kulturalnej w ramach KZR uzyskał A. Zajączkowski.

Korespondencja Włodzimierza Zajączkowskiego do Seraji Szapszała, orientalisty do orientalisty i Karaima do Karaima, stanowi istotne źródło informacji o pierwszych latach powojennej odbudowy polskiej orientalistyki i życia społecznego polskich Karaimów.

\section{Publikacje poświęcone Włodzimierzowi Zajączkowskiemu}

Dubiński, A., Prof.Dr. Włodzimierz Zajaczkowski. On the occasion of his $65^{\text {th }}$ birthday. Bibliography of the works of Włodzimierz Zajaczkowski, „Ural-Altaische Jahrbücher” 1981, Neue Folge, t. 1, s. 255-269.

Dubiński, A., Włodzimierz Zajączkowski in memoriam, „Przegląd Orientalistyczny” 1983, nr 1-4 (125-128), s. 183-185.

Godzińska, M., Włodzimierz Zajączkowski - badacz folkloru ludów tureckich, „Almanach Karaimski” 2014, nr. 3, s. 37-40.

Siemieniec-Gołaś, E., Włodzimierz Zajączkowski (1914-1982), „Złota Księga Wydziału Filologicznego", Kraków 2000, s. 673-675.

Sulimowicz, A., Polscy turkolodzy Karaimi. Od przedmiotu do podmiotu badań naukowych, [w:] Machul-Telus, B. (red.), „Karaimi”, Warszawa 2012, s. 136-140.

Tryjarski, E., O Profesorze Włodzimierzu Zajączkowskim i wspólnej z nim podróży do Jerozolimy, „Przegląd Orientalistyczny” 2001, nr 3-4 (198-199), s. 260-265. 


\section{LISTY}

\section{Nr I}

Kraków 17 II 1947

Wielce Szanowny i Drogi Adonienu' ${ }^{18}$,

Wysłałem dzisiaj listem poleconym zaświadczenie potwierdzające, że na podstawie przedstawionej w 1930 r. dysertacji pt. „Kyrym karaj tiurkleri” w Instytucie Dalekiego Wschodu Uniwersytetu Lwowskiego otrzymał Pan stopień doktora filozofii języków orientalnych.

Proszę mi wybaczyć moje długie milczenie, ale niesprzyjające okoliczności nie pozwalały mi na napisanie do Pana choćby kilku słów. Teraz jestem już mniej więcej normalnie urządzony, więc mogę wreszcie uczynić zadość wymogom grzeczności.

Zapewne wie już Pan, że pracuję przy sprzedaży książek w Polskiej Akademii Umiejętności (razem z Marią Wł[adysławowną] Kotwicz) ${ }^{19}$ oprócz tego zajmuję się zbieraniem materiału leksykograficznego do słownika karaimskiego. Przede wszystkim wykorzystuję halickie przekłady Pisma Św[iętego], których komplet znajduje się u prof. Kowalskiego ${ }^{20}$.

Nie zwróciłem się w Pańskiej sprawie do prof. Kowalskiego znając jego skrupulatność.

18 Adonienu (z hebr. adonenu - 'nasz pan') - tytuł używany przez Karaimów w stosunku do S. Szapszała jako hachana karaimskiego.

19 Maria Kotwiczówna (1897-1978), córka prof. dr. Władysława Kotwicza i jego najbliższa współpracownica, bibliografka i archiwistka. Po „repatriacji” w 1945 r. do Krakowa była kierowniczką referatu wymiany zagranicznej wydawnictw PAU.

20 Prof. dr Tadeusz Kowalski (1889-1948), orientalista, w 1919 r. objął Katedrę Filologii Orientalnej utworzoną na Uniwersytecie Jagiellońskim. Sekretarz generalny Polskiej Akademii Umiejętności od 1939 r. Rękopiśmienne tłumaczenia Pięcioksięgu i ksiąg Pism na język karaimski, sporządzone przez Józefa Mortkowicza (1802-1884), halickiego hazzana i kopistę, przekazał prof. Kowalskiemu uczestnik jego seminarium, przed wojną student medycyny Nowach Szulimowicz (list z 18 X 1943, archiwum prywatne A. Kowalskiej-Lewickiej). 
Bardzo dobrze odniósł się do mojej prośby dr Marian Lewicki ${ }^{21}$ (uczeń i asystent prof. Kotwicza ${ }^{22}$, który miał objąć po nim katedrę). Bez odkładania na dno szuflady spełnił moją prośbę, tak że mogłem wysłać zaświadczenie. Ponieważ to wszystko wymaga, aby tyjitma ${ }^{23}$, myślę, że pozostanie entre nous.

Co do książek, to niestety nie mogę Pana zadowolić, bowiem na wysyłanie książek potrzebne jest pozwolenie Ministerstwa Żeglugi i Handlu Zagranicznego, a takiego pozwolenia osoby prywatne nie otrzymują. Inną przeszkodą przesyłania jest obcy język tekstów azerbejdżańskich, którego tu się nie używa.

28 II i 1 III odbędzie się w Krakowie zjazd orientalistów. Wielu uczonych tej specjalności zmarło, ale mimo wszystko dzięki energii prof. Kowalskiego orientalistyka zaczyna się podnosić. Wyszła I część dysertacji dra T. Lewickiego Polska $i$ inne państwa u arabskiego geografa XII $w$. Idrisiego ${ }^{24}$, prof. Kowalski opublikował Relację Ibrahima ibn Jakuba z podróży do krajów słowiańskich.... ${ }^{25}$. Ukazał się I tom „Myśli Karaimskiej” z artykułami prof. Kowalskiego Próba charakterystyki języków tureckich i prof. A. Zajączkowskiego O kulturze chazarskiej.... ${ }^{26}$.

Teraz przygotowuje się II tom „Myśli Karaimskiej”, do którego ja także przygotowałem coś: 1) O przysłowiach i powiedzeniach Karaimów trockich ${ }^{27}$,2) Charakterystyka literackiej działalności A. Mardkowicza ${ }^{28}$ i 3) artykulik o legendach i podaniach, zebranych przez bł. p. A.J. Szyszmana ${ }^{29}$.

21 Prof. dr Marian Lewicki (1908-1955), mongolista, ałtaista, kierownik katedry Filologii Ludów Azji Środkowej UJ.

22 Prof. dr Władysław Kotwicz (1872-1944), mongolista, ałtaista, od 1924 r. kierownik Katedry Filologii Dalekiego Wschodu Uniwersytetu Jana Kazimierza we Lwowie i prezes Polskiego Towarzystwa Orientalistycznego.

23 Karaim. 'milczeć'.

24 T. Lewicki, Polska i kraje sasiednie w świetle „Ksiegi Rogera”, geografa arabskiego $z$ XII $w$. al-Idrīsì'ego. Cz. I (Uwagi ogólne, tekst arabski, tłumaczenia), (=Prace Komisji Orientalistycznej nr 34), Kraków 1945.

25 T. Kowalski, Relacja Ibrāhīma Ibn Jakūba z podróży do krajów słowiańskich $w$ przekazie al-Bekriego (= Pomniki dziejowe Polski, seria 2, t. 1). Wydawnictwa Komisji Historycznej. Polska Akademia Umiejętności, t. 84, Kraków 1946.

26 A. Zajączkowski, O kulturze chazarskiej i jej spadkobiercach, „Myśl Karaimska”. Seria Nowa, 1946, t. 1, s. 5-34.

27 W. Zajączkowski, Przysłowia, powiedzenia i formulki Karaimów trockich, „Myśl Karaimska”. Seria Nowa, 1947, t. 2, s. 53-63.

28 Artykuł pod takim tytułem nie został ostatecznie opublikowany. Zebrane materiały W. Zajączkowski wykorzystał, przygotowując poświęcone Mardkowiczowi hasło do Polskiego Stownika Biograficznego.

29 W. Zajączkowski, Legendy i podania karaimskie, SPAU 1949, t. L, s. 491-492. 
W Krakowie mieszkają Maria Osipowna z Marianką ${ }^{30}$. Przekazałem im Pańskie pozdrowienia. Bardzo się ucieszyły i prosiły serdecznie podziękować i pokłonić się z całego serca.

Podczas wizyt u Zajączkowskich często wspominamy Pana i wielce szanowną Wierę Isakowną ${ }^{31}$ oraz wszystkich znajomych. Bardzo tęsknimy za Wami.

Proszę przekazać najserdeczniejsze pozdrowienia Wierze Isakownie z ucałowaniem rączek.

Serdecznie pozdrawiam i ręce Pańskie całuję prosząc o błogosławieństwo, pozostaję na zawsze oddany, poważający i kochający Pana

Wołodia

\section{Nr 2}

Kraków 27 IV 1947

Wielce Szanowny i Drogi Adonienu,

Serdecznie dziękuję za Pański list z 12. III, który mnie ucieszył, bowiem niepokoiłem się o los mojego listu poleconego. Teraz dowiedziawszy się, że otrzymał go Pan, uspokoiłem się. Bardzo się cieszę, że zaświadczenie w czymś Panu pomoże.

W czasie wakacji od 2 do 17 IV byłem nieobecny w Krakowie. Odwiedzałem Jutkiewiczów $^{32}$ w Pruszkowie, byłem kilka dni u profesora Zajączkowskiego ${ }^{33}$,

30 Maria Zajączkowska (1889-1969), córka Józefa Łopatto, żona mec. Izaaka Zajączkowskiego. Po śmierci męża w marcu 1945 r. „repatriowała” się do Krakowa wraz z córką Marianną (1925-1990), później żoną Zygmunta Abrahamowicza, turkologa.

31 Wiera Szapszał (1871-1950), z domu Egiz, żona S. Szapszała.

32 Izajasz Jutkiewicz „Waligóra” (1897-1973), przedsiębiorca w branży papierniczej i jego żona, Nadzieja z Dubińskich (1906-1990) jeszcze przed wojną osiedli w Warszawie. Ich dom w Pruszkowie przy ul. Przemysłowej był przystanią dla Karaimów, którzy tuż przed zakończeniem wojny i po niej zdecydowali się opuścić dawne siedziby.

33 Prof. dr hab. Ananiasz Zajączkowski (1903-1970), orientalista, twórca warszawskiej turkologii, od 1933 r. kierownik Seminarium Turkologicznego w nowopowstałym Instytucie Orientalistycznym UW. Po wojnie zajął się odbudową studiów orientalistycznych w Warszawie, pełniąc w latach 1946-1950 funkcję dyrektora Instytutu. W latach 1946-1947 mieszkał z żoną, Nadzieją z Jutkiewiczów (1901-1983) i dziećmi: Aleksandrem (1930-1988), Marią Emilią (1939) i Elżbietą Bianą (1944) w Podkowie Leśnej przy ul. Sarniej. 
u Szpakowskich (z Łucka) ${ }^{34}$, widziałem się z rodziną B. J. Szyszmana ${ }^{35}$. Święta spędziłem w uroczystym nastroju dzięki uprzejmości i gościnności Jutkiewicza i jego rodziny w Pruszkowie, Profesora i innych współbraci. Odbyło się uroczyste nabożeństwo w 1. i ostatni dzień, odprawiał profesor Ananiasz, tak że wszyscy byli wzruszeni i zadowoleni. W Podkowie Leśnej wynajęto osobny dom $^{36}$ na potrzeby społeczności, do którego przychodzą w niedziele i na święta. Wszyscy mają się nieźle, wszyscy Pana wspominają.

Przy okazji byłem kilka dni także u mojego brata, Romusia ${ }^{37}$. Prowadzi zakład zegarmistrzowski. Wiedzie mu się nieźle. W ogóle wakacje spędziłem bardzo dobrze, zobaczyłem krewnych i znajomych, którzy długo na mnie czekali.

Po powrocie do domu zabrałem się ponownie do pracy. Wybrałem już 2100 słów z Psałterza. Teraz opracowuję Przypowieści Salomonowe. Dziękuję bardzo za przysłowie, nie znałem go dotychczas. Gdy dostanę korektę, postaram się włączyć je do artykułu ${ }^{38}$.

Trwają przygotowania do druku XV t. „Rocznika Orientalistycznego”, którego redaktorem został wybrany prof. Kowalski. Jednocześnie jest on prezesem Polskiego Towarzystwa Orientalistycznego, wiceprezesem prof. A. Zajączkowski,

34 Zachariasz Szpakowski (1901-1986), urzędnik Izby Skarbowej w Łucku i jego siostra, Alina Robaczewska (1904-1991) z synem Eugeniuszem (1931-2003) przyjechali w styczniu 1944 r. z Łucka do Zielonki pod Warszawą.

35 Borys Jakowlewicz Szyszman (1877-1952), krymski Karaim, wileński przedsiębiorca i kupiec tytoniowy, filantrop. Po wojnie opuścił Wilno z żoną Ireną z d. Kojczu (1882-1978), synem Michałem (1910-2002) i córką Tamarą Szpakowską (1913-2010). Zamieszkali początkowo w Podkowie Leśnej, później w Warszawie.

36 Znajdował się przy ulicy Bukowej 4.

37 Romuald Zajączkowski (1922-1993), młodszy brat Włodzimierza. Po wojnie wraz z przyszłą żoną, Leokadią Łabzak i jej rodziną otrzymali „przydział repatriacyjny” do Krakowa, ale zatrzymali się w Toruniu, który tak im się spodobał, że postanowili się tam osiedlić.

38 Chodzi zapewne o wspomniany we wcześniejszym liście artykuł Przysłowia, powiedzenia i formułki Karaimów trockich. 
sekretarzem dr M. Lewicki, skarbnikiem ks. prof. A. Klawek ${ }^{39}$, członkami Zarządu prof. J. Kuryłowicz ${ }^{40}$ i prof. H. Willman-Grabowska ${ }^{41}$.

Po ciężkiej zimie zaczęła się u nas wiosna. Wszystko się zazieleniło, ociepliło się, chodzimy już bez płaszczy.

Prof. Kowalski wraz z rodziną przekazuje Panu i Wierze Isakownie serdeczne pozdrowienia.

Adwokat Nowachowicz ${ }^{42} \mathrm{z}$ małżonką także przesyła ukłony.

Maria Osipowna z Marianką przesyłają Panu i Wierze Isakownej serdeczne pozdrowienia.

Całuję Pańskie ręce i Wiery Isakowny, pozostaję zawsze oddany i szczerze Pana szanujący

Wołodia

Korzystając z uprzejmości mojego współpracownika, ja także przesyłam Panu, wielce szanowny Seraja Markowiczu, najlepsze pozdrowienia z dalekiego Krakowa. Mam nadzieję, że niedługo być może zobaczymy się z Panem. Często wspominam obojga Państwa i tę serdeczność, którą mi okazywaliście.

Zawsze oddana Panu

M. Kotwicz

Serdeczne pozdrowienia dla Wiery Isakowny.

39 Ksiądz prof. dr teologii Aleksy Klawek (1890-1969), biblista i orientalista asyriolog, kierownik Zakładu Nauk Biblijnych na Uniwersytecie Jana Kazimierza we Lwowie, po wojnie dziekan Wydziału Teologicznego UJ.

40 Prof. dr hab. Jerzy Kuryłowicz (1895-1978), językoznawca, indoeuropeista i semitolog, 1929-1939 profesor językoznawstwa ogólnego na Uniwersytecie Jana Kazimierza we Lwowie, w latach 1948-1965 kierownik Katedry Językoznawstwa Ogólnego UJ.

41 Prof. dr hab. Helena Willman-Grabowska (1870-1957), indolog, iranista, religioznawca, pierwsza kobieta wykładowca i profesor (mianowana w 1928 r.) w historii Uniwersytetu Jagiellońskiego, kierowała Katedrą Sanskrytu i Filologii Indyjskiej. Jesienią 1947 r. usunięta z uczelni i przeniesiona na emeryturę. W latach 1948-1952 przewodnicząca Komisji Orientalistycznej PAU.

42 Zachariasz Nowachowicz (1883-1960), dr prawa, adwokat, działacz społeczny i prezes gminy karaimskiej w Haliczu. Jego żona, Sabina z Samuelowiczów (1885-1960), nauczycielka, była animatorką życia kulturalnego i społecznego, prezeską Koła Pań Karaimskich w Haliczu. Wiosną 1944 r. Nowachowiczowie wyjechali z Halicza do Krakowa (zamieszkali przy ul. Ariańskiej 6 m. 7), a następnie osiedli w Chrzanowie, gdzie Zachariasz prowadził kancelarię notarialną. 


\section{$\mathrm{Nr} 3$}

\section{Kraków 7 XI 1947}

Wielce Szanowny Adonienu,

Już dawno miałem napisać do Pana o swoim życiu, ale wciąż rozmaite przeszkody nie pozwalały mi zrealizować tego postanowienia. Teraz wreszcie znalazłem chwilę, aby napisać do Pana ten list. Dzięki Bogu jestem żywy i zdrowy. Pracuję jak dawniej w Akademii Umiejętności przy rozsyłaniu książek - wydawnictw Akademii, pod kierownictwem Marii Władysławowny Kotwicz, po obiedzie [zaś] przygotowuję materiał leksykograficzny do słownika karaimskiego - wybrałem już słowa z ksiąg: Psalmów, Przypowieści Salomona, Rut, Eklezjasty, Estery, Daniela. Do tej pory wybrałem ok. 3000 słów. Oprócz tego zajmuję się moją pracą doktorską o Gagauzach. Jak Pan już wie, wszystkie moje notatki przepadły w czasie wojny, tak że trzeba wszystko odtwarzać na nowo. Tak więc praca pomału posuwa się naprzód. Od czasu do czasu bywam u Marii Osipowny i Marianny, gdzie często wspominamy wszystkich znajomych i krewnych. To jedyny dom oprócz prof. Kowalskiego, w którym zawsze można przyjemnie spędzić czas.

W połowie listopada czekamy na powrót z Turcji prof. Kowalskiego, który przysłał mi 2 kartki pocztowe ze Stambułu.

Powrócił do Krakowa dr T. Lewicki ${ }^{43}$ (arabista), tak że zebrali się tutaj wybitni orientaliści. Marian Lewicki prowadzi wykłady o napisach starotureckich.

Drukuje się XV tom „Rocznika Orientalistycznego”, w którym znajdzie się artykuł prof. Kowalskiego Les Turcs dans le Šah-name, prof. Kotwicza z mongolistyki, także M. Lewickiego, prof. A. Zajączkowskiego Remarques concernant les études sémantiques turques, prof. Kuryłowicza $\mathrm{z}$ indologii, prof. Słuszkiewicza ${ }^{44}$ II część studiów ormiańsko-tureckich i in. We Wrocławiu drukuje się monografia śp. prof. Kotwicza o J. Kowalewskim.

43 Prof. dr Tadeusz Lewicki (1906-1992), orientalista, arabista, historyk mediewista. Przed wojną związany z Uniwersytetem Jana Kazimierza we Lwowie, w czasie wojny jeniec oflagu Murnau i żołnierz II Korpusu. W 1947 r. przyjechał do Krakowa, gdzie w 1948 objął po T. Kowalskim, swoim teściu, Katedrę Filologii Orientalnej i kierował nią do przejścia na emeryturę w 1976 r.

44 Prof. dr Eugeniusz Słuszkiewicz (1901-1981), językoznawca, indolog, armenista, pracował na Uniwersytecie Mikołaja Kopernika w Toruniu, a następnie został mianowany kierownikiem Katedry Filologii Indyjskiej UW. 
Prof. Willman-Grabowska od 1 stycznia przechodzi na emeryturę. Nie wiadomo, kto ją zastąpi, czy prof. Kuryłowicz ${ }^{45}$, czy też Słuszkiewicz.

Niestety, nie otrzymujemy niczego z ZSRR, a tam wychodzi mnóstwo książek orientalistycznych. Posłałem Pańskie studia azerbejdżańskie akad[emikowi] Gordlewskiemu $^{46}$ (został wybrany akademikiem z okazji 70-lecia urodzin). Ale nie otrzymałem od niego wiadomości. Interesuje mnie jego praca o Seldżukach ${ }^{47}$. Oprócz tego niejaki Kononow ${ }^{48}$ wydał w Akademii Nauk ZSRR Turecka gramatykę. Dla nas jest ona niedostępna. W ogóle bardzo trudno o literaturę.

Jeśli to Panu nie sprawi kłopotu, prosiłbym o wiadomości o tym, co pozostawił bł. p. r[ibbi ${ }^{49}$ Józef Łobanos $^{50}$ z przekładów Mickiewicza. Czy to prawda, że jest przekład Pana Tadeusza? Interesuje mnie to dlatego, że może uda mi się przygotować artykuł o karaimskich przekładach Mickiewicza. Byłbym bardzo wdzięczny za tę informację.

Prof. A. Zajączkowski oddał do redakcji Słownika Biograficznego artykuł o Ezrze $\mathrm{e}^{51}$ - lekarzu Jana Kazimierza oraz o A. Firkowiczu (Hadży-Babie) ${ }^{52}$. Może uda mi się umieścić artykulik o Bogusławie Firkowiczu ${ }^{53}$.

Serdecznie pozdrawiam i ręce całuję czcigodnej Wierze Isakownie.

Pańskie ręce całuję i proszę o błogosławieństwo.

Oddany

Władimir

4514 XI 1947 r. Senat UJ powołał prof. dr Jerzego Kuryłowicza na stanowisko kierownika Katedry Filologii Indyjskiej UJ.

46 Władimir Aleksandrowicz Gordlewskij (1876-1956), radziecki turkolog, autor licznych prac z zakresu języka, literatury, folkloru i historii Turcji. W latach 1938-1956 kierownik działu języka i literatury krajów Bliskiego Wschodu Instytutu Wschodoznawstwa Akademii Nauk ZSRR.

47 Chodzi o monografię Gosudarstvo Sel'džukidov v Maloj Azii, wydaną w Moskwie w 1941 r., o której jest mowa w także dalej, w liście nr 6.

48 Andriej Nikołajewicz Kononow (1906-1986), radziecki lingwista, turkolog, od 1934 r. wykładowca języka tureckiego, a od 1949 kierownik katedry filologii tureckiej na Wydziale Wschodnim Uniwersytetu w Leningradzie. A.N. Kononow przygotował i wydał kilka opracowań gramatyki tureckiej: Grammatika sovremennogo tureckogo âzyka (współaut. H. Dżewdet-zade), wyd. 1934, Grammatika tureckogo âzyka, 1948, Grammatika sovremennogo tureckogo literaturnogo âzyka, wyd. 1956.

49 Ribbi - tytuł używany w stosunku do osoby posiadającej wykształcenie religijne, duchownego karaimskiego.

50 Józef Łobanos (1878-1947), duchowny karaimski, hazzan w Wilnie i Łucku, poeta.

51 A. Zajączkowski, Ezra ben Nisan (Nisanowicz), PSB, 1948, t. 6, z. 29, s. 333.

52 A. Zajączkowski, Firkowicz, Abraham syn Samuela, PSB, 1948, t. 6, z. 30, s. 472-473.

53 W. Zajączkowski, Firkowicz, Bogusław, PSB, 1948, t. 6, z. 30, s. 473-474. 


\section{$\mathrm{Nr}_{4}$}

Kraków 3 I 1948

Wielce Szanowny i Czcigodny Adonienu,

Serdecznie Panu dziękuję za Pański drogi list, w którym otrzymałem wiele interesujących wiadomości. Ferie z okazji Bożego Narodzenia spędziłem u brata w Toruniu. W drodze powrotnej zajechałem do Jutkiewiczów w Pruszkowie, gdzie przy gościnnym stole piliśmy Pańskie zdrowie. Była tam także Tatiana Jakowlewna Szpakowska ${ }^{54}$, która wszystkich wspominała. Drugiego dnia odwiedziłem w Warszawie prof. A. Zajączkowskiego, który po 3-letniej poniewierce otrzymał własne mieszkanie, niewielkie, co prawda, ale przytulne, gdzie może żyć i spokojnie pracować55. Wszyscy są bardzo zdumieni nietaktownymi postępkami R[ibbi] Rafała ${ }^{56}$, a Ministerstwo po prostu nie chce go znać ani widzieć, mówią, że nawet gdyby wszyscy go wybrali, to Departament w żadnym wypadku go nie zatwierdzi. Najgorzej, że prof. Ananiasz [Zajączkowski] kategorycznie odmawia przyjęcia stanowiska Prezesa, tak więc sytuacja organizacji przedstawia się bardzo smutno. W dużym stopniu winna jest temu sama społeczność, która nie uznała za stosowne powstrzymać zbyt energicznych poczynań podejmowanych przez R[ibbi] Rafała i nijak nie starała

54 Tatiana Szpakowska (1879-1957), urodzona w Trokach, po wojnie mieszkała z córką, Zofią, i zięciem, Szymonem Nowickim z Łucka, w Warszawie.

55 Przed wojną A. Zajączkowski mieszkał z rodziną na Starym Mieście przy ul. Brzozowej 12. Podczas Powstania, po upadku Starego Miasta 2 września 1944 r. zostali stamtąd wypędzeni i trafili do obozu przejściowego w Pruszkowie. Następnie z schroniska RGO w Milanówku przenieśli się do wynajętego pokoju przy ul. Podgórnej. Kolejne adresy zamieszkania to ul. Emaus i ul. Gnieźnieńska w Krakowie oraz ul. Borsucza i ul. Sarnia w Podkowie Leśnej pod Warszawą. Wreszcie w październiku 1947 r. przenieśli się do Warszawy, do dwupokojowego mieszkania w domu Spółdzielni Profesorów UW przy ul. Sewerynów 6.

56 Rafał Abkowicz (1896-1992), hazzan w Trokach (1919-1920), od 1929 r. w Łucku, w 1939 r. w Wilnie. Po wojnie wyjechał wraz z żoną Natalią z Firkowiczów i dwoma synami na Dolny Śląsk do Otmuchowa, gdzie już przebywali zdemobilizowani dwaj starsi synowie. Ostatecznie osiadł we Wrocławiu, gdzie zorganizował w mieszkaniu dom modlitwy. Oponent prof. A. Zajączkowskiego, inaczej wyobrażał sobie przyszłość Karaimów w powojennej Polsce. Por. Listy Ananiasza Zajaczkowskiego do Seraji Szapszała, „Almanach Karaimski” 2013, nr 2, s. 158-160; Abkowicz, M., Karaimskie życie społeczne w Polsce po 1945 roku, [w:] Machul-Telus B., Karaimi, Warszawa 2012, s. $185-187$. 
się powściągnąć go w nieprzemyślanych działaniach. Żal po prostu całej do tej pory wykonanej pracy. Cała konstrukcja tak troskliwie budowana upadnie za jednym zamachem i potem będzie trudno ją ponownie stworzyć. My wszyscy, którzy rozumiemy tę sytuację, cierpimy z całej duszy, ale nie możemy opanować zawieruchy, tym bardziej, że wiele osób odnosi się do tego obojętnie. Mimo wszystko nie tracimy nadziei, że może jakoś tę sprawę da się naprawić. W takich ciężkich chwilach bardzo silnie odczuwamy brak Pańskiego wielkiego autorytetu, który przywołałby wszystkich do porządku.

Bardzo Panu dziękuję za trudy poniesione w związku z wysyłką do mnie książek, które otrzymałem punktualnie. Słownik sprzedałem prof. Słuszkiewiczowi, który prosił przekazać Panu serdeczne pozdrowienia. Co zaś do Pańskich „Tekstów azerbejdżańskich” ${ }^{57}$ przy najbliższej okazji postaram się wysłać do Pana 3 egzemplarze. Bardzo się uradowałem wiadomością, że drukuje Pan artykuł o monetach. Niecierpliwie będę czekał na odbitkę Pańskiej pracy. Prof. Kowalski otrzymał list Pański i był uprzejmy przygotować zaświadczenie, które dołączam do tego listu. Ponieważ zmieniły się warunki, powstał zamiar zamiany tytułu „Myśli Karaimskiej” na „Przegląd Orientalistyczny”, charakter czasopisma nie zmieni się, a zyska ono szerszy zasięg.

„Rocznik Orientalistyczny” drukuje się i powinien być gotów do lipca br., czyli na XXI Międzynarodowy Kongres Orientalistów w Paryżu. Komisja Orientalistyczna rozwija się dobrze. W grudniu odbyło się posiedzenie z wykładami ks. prof. Klawka Oetymologii imienia Maria ${ }^{58}$ i dr T. Lewickiego O grodzisz$c z u$ Sutaska u Idrisiego ${ }^{59}$. Na 10 stycznia wyznaczono następne posiedzenie z wykładem dr T. Lewickiego O państwie Wiślan-Chorwatów w opisie al-Mas'udi’ego ${ }^{60}$ oraz dr M. Lewickiego o języku mongolskim w chińskiej transkrypcji XIV w. Najprawdopodobniej to prof. Kuryłowicz zacznie wykłady zamiast prof. Willman-Grabowskiej, która odchodzi na emeryturę.

57 Chodzi o Próby literatury ludowej Turków z Azerbejdżanu perskiego, Prace Komisji Orientalistycznej PAU nr 18, Kraków 1935.

58 A. Klawek, Etymologia imienia Maria, „Polonia Sacra” 1948, nr 1, t. I, z. 2, s. 176-184.

59 T. Lewicki, Ze studiów nad toponomastyka Rusi $w$ dziele geografa arabskiego al-Idrisiego (XII w.). *Sutaska - Saciaska, SPAU 1947, t. 48, nr 10, s. 402-407. Rec. W. Zajączkowski, PO 1954, nr 2 (10), s. 183.

60 T. Lewicki, Państwo Wiślan-Chorwatów wopisie al-Mas'udīe ego, SPAU 1948, t. 49, nr 1, s. 24-34. Rec. W. Zajączkowski. PO 1954, nr 2 (10), s. 183. 
Maria Władysławowna dziękuje za wiadomości o jej domu i cieszy się, że opiekują się nim Łopatto ${ }^{61}$.

Całuję Pańskie ręce i Wiery Isakowny i proszę o Pańskie błogosławieństwo

Serdecznie oddany

Wołodia

\section{$\operatorname{Nr} 5$}

Kraków 16 III 1948

Wielce Szanowny Adonienu,

Wczoraj otrzymałem wysłane przez Pana czasopisma „K[araj] A[wazy]”, za które składam serdeczne słowa wdzięczności, ponieważ tutaj nigdzie nie mogłem znaleźć nr 11. Do kompletu brakuje mi jeszcze nr 9 i wtedy chciałbym oddać [całość] do oprawy. Nawet u rodziny bł. p. Mardkowicza ${ }^{62}$, u której kupiłem nr 1-8, 10 i 12, nie zostały nr 9 i 11 i dlatego pozwoliłem sobie niepokoić Pana i nadal proszę, może uda się gdziekolwiek znaleźć nr 9, może u szammasza J. Poziemskiego ${ }^{63}$ albo u Ułłu Hazzana w Trokach ${ }^{64}$. Będę Panu bardzo zobowiązany.

Moje życie toczy się po dawnemu. Teraz na skutek choroby prof. Kowalskiego praca o Gagauzach zatrzymała się, ponieważ nie mogę niepokoić chorego Profesora problemami, które wydają mi się zbyt skomplikowane. Może Bóg da, że prof. Kowalski niedługo wyzdrowieje i będę mógł ukończyć swoją pracę.

Pewnie otrzymał Pan już zaproszenie Komitetu Jubileuszowego ku czci prof. Kowalskiego i jego 60-lecia. Mam zaszczyt być członkiem tego Komitetu ${ }^{65}$.

61 Chodzi najprawdopodobniej o domek w Czarnym Borze, w którym w czasie wojny mieszkał prof. W. Kotwicz z córką i gdzie zmarł. Aleksy Łopatto (1891-1968) i jego żona Wanda jeszcze przed wojną wybudowali w tej miejscowości dom, w którym mieszkali do wyjazdu do Wrocławia w $1966 \mathrm{r}$.

62 Aleksander Mardkowicz (1875-1944), z zawodu notariusz, karaimski pisarz i wydawca z Łucka.

63 Jakub Szymon Poziemski (1879-1956) syn Józefa, szammasz kienesy w Wilnie.

64 Szymon (Szemaja) Firkowicz (1898-1982), od 1920 r. hazzan w Trokach, działacz społeczny, poeta i pisarz karaimski.

65 Komitet Organizacyjny pod patronatem Prezesa Polskiej Akademii Umiejętności, prof. dr Kazimierza Nitscha w składzie: przewodniczący prof. dr Ananiasz Zajączkowski, sekretarz dr Marian Lewicki, członkowie: prof. dr Witold Jabłoński, ks. prof. dr Aleksy Klawek, dr Tadeusz Lewicki, prof. dr Helena Willman-Grabowska, 
Do Księgi Pamiątkowej przygotowuję bibliografię prof. Kowalskiego, a oprócz tego chciałbym zamieścić tam karaimski sennik, w skład którego wejdzie 180 objaśnień snów według rękopisu z Poniewieża. Czekamy i na Pański artykuł, który z przyjemnością zamieścimy w Księdze. Myślę, że napisze Pan w jęz. rosyjskim, a my przetłumaczymy na polski. Pożądanym by było napisać na maszynie do pisania, aby nie było wątpliwości, jak przeczytać jakieś słowo.

Interesuje mnie spis oryginalnych utworów i przekładów bł. p. ribbi J. Łobanosa. Chciałbym zamieścić o nim wspomnienie w „Myśli Karaimskiej”. Oprócz tego w bieżącym roku przypada 150 rocznica urodzin A. Mickiewicza (24 XII 1798) i dlatego chciałbym przygotować artykuł o karaimskich przekładach Mickiewicza. Może Pan wie czy obok przekładów Sz. Firkowicza i prof. A. Zajączkowskiego (7 sonetów krymskich) oraz Alpuhary [przełożonej przez] A. Mardkowicza istnieją także przekłady bł. p. J. Łobanosa? Chciałbym znać chociaż nazwy utworów. Czy w całości przetłumaczył Pana Tadeusza? Byłbym Panu bardzo wdzięczny za odpowiedź na interesujące mnie pytania.

Jeszcze jedna prośba. Jak Pan wie, XIV t. „Rocznika Orientalistycznego” wyszedł w 1939 r. i nie zdążono go rozesłać za granicę. Teraz wiele osób pyta o XIV t. Ponieważ pod Pana opieką pozostała część nakładu, czy mógłby Pan stopniowo posyłać „Rocznik Orientalistyczny” [po] 2 egzemplarze do mnie, a opłaty pocztowe pokryje mój ojciec? Na próbę proszę przysłać za pierwszym razem 2 egz., a jeśli otrzymam pomyślnie, powiadomimy i Pan, jeśli to możliwe, będzie kontynuował wysyłkę. Proszą o to dr M. Lewicki i M. Kotwicz.

Całuję Pańskie i Wiery Isakowny ręce i pozostaję oddany

Władimir

\section{Nr 6}

Kraków 19 XI 1948

Wielce Szanowny i Czcigodny Adonienu,

Od dawna zabieram się do napisania kilku słów do Pana, ale różne przyczyny przeszkadzały mi w wykonaniu tego zamiaru. Dzisiaj odłożyłem wszystko i postanowiłem podzielić się z Panem wiadomościami o uroczystości 75-lecia.

mgr Włodzimierz Zajączkowski, ukonstytuował się 1 marca 1948 r. i rozesłał pismo zapraszające do składania artykułów do Księgi. Pismo takie otrzymał m.in. również S. Szapszał. Księga dla uczczenia pamięci Tadeusza Kowalskiego (1889-1948) ukazała się w 1953 r. jako XVII tom „Rocznika Orientalistycznego”. 
W końcu października odbyła się uroczystość poświęcona jubileuszowi 75-lecia Polskiej Akademii Umiejętności. Przyjechało wiele gości z różnych krajów Europy. Delegacji radzieckiej przewodniczył akad[emik] Grekow ${ }^{66}$, który wygłosił bardzo interesujący wykład, a oprócz niego przybyli m.in. bizantynista prof. Gregoire ${ }^{67}$ z Belgii, Levi della Vida ${ }^{68}$, arabista $z$ Włoch, turkolog Németh ${ }^{69}$ z Budapesztu. Németh po obchodach jubileuszu pozostał jeszcze na $10 \mathrm{dni}$, aby zaznajomić się z krakowskimi bibliotekami orientalistycznymi; bardzo mu się podobała biblioteka śp. prof. Kotwicza ${ }^{70}$. Prof. Németh wypytywał i o Pana, jak Pan się miewa.

Po zgonie prof. Kowalskiego pełniącym obowiązki profesora w naszej katedrze wyznaczony został dr Tadeusz Lewicki (arabista), zajęcia z turkologii prowadzi Marian Lewicki (ałtaista - uczeń Kotwicza). W ten sposób w wykładach nie nastąpiła przerwa. Przewodniczącą Komisji Orientalistycznej została wybrana prof. Willman-Grabowska, sekretarzem dr Marian Lewicki. Kończy się druk XV t. „Rocznika Orientalistycznego”, w którym znajdzie się i mój artykuł o karaimskich snach według rękopisu z Poniewieża ${ }^{71}$. Oprócz tego na posiedzeniu Komisji Orientalistycznej miałem wykład o litewskich elementach w języku Karaimów z Trok ${ }^{72}$. Jak tylko się ukaże drukiem, nie zwlekając prześlę Panu odbitkę. Na posiedzeniu Komisji Literatury Polskiej mówiłem o przekładach Mickiewicza na język karaimski ${ }^{73}$. Postaram się także przysłać Panu

66 Borys Dmitrewicz Grekow (1882-1953), radziecki historyk, autor prac o dziejach dawnej Rusi i Złotej Ordy, profesor uniwersytetów w Moskwie i Petersburgu. W 1947 r. został członkiem Polskiej Akademii Umiejętności.

67 Henri Gregoire (1881-1964), belgijski historyk hellenista i bizantynista, pisarz, profesor Uniwersytetu w Brukseli.

68 Giorgio Levi della Vida (1886-1967), włoski orientalista, semitysta, historyk religii. W 1939 r. wyjechał do Stanów Zjednoczonych, gdzie spędził wojnę. W 1945 r. powrócił do Włoch, na uniwersytecie w Rzymie wykładał dzieje i kulturę islamu.

69 Gyula Németh (1890-1976), węgierski językoznawca, turkolog i ałtaista. Por. W. Zajączkowski, Gyula Németh (1890-1976), PO 1977, nr 104, s. 367-368.

70 W 1964 r. biblioteka W. Kotwicza została przekazana przez M. Kotwiczównę jako wydzielony księgozbiór w darze dla Katedry Filologii Ludów Azji Środkowej Instytutu Orientalistycznego UW. Obecnie znajduje się w Bibliotece Mongolistyki i Tybetologii Wydziału Orientalistycznego UW.

71 W. Zajączkowski, Un livre de songes caraime, RO 1949, t. 15, s. 339-356.

72 W. Zajączkowski, Zapożyczenia litewskie w języku Karaimów trockich, SPAU, 1948, t. XLIX, s. 360-362.

73 W. Zajączkowski, Przekłady Mickiewicza na język karaimski, SPAU 1948, t. XLIX, s. 391-392. 
odbitkę. Na ostatnim posiedzeniu Komisji Orientalistycznej przedstawiłem pozostałości języka Tatarów ${ }^{74}$. Tak że pomalutku posuwam się do przodu. Niebawem zacznie się drukować księga poświęcona pamięci śp. prof. Kowalskiego. Już otrzymaliśmy ponad 20 artykułów. Mamy nadzieję, że do czerwca będzie gotowa. Po XV „Roczniku Orientalistycznym”, XVI będzie poświęcony pamięci śp. prof. Kotwicza. Było by wielce pożądanym, gdyby mógł Pan przysłać swój artykuł do tego tomu, bo mieliście Panowie bardzo dobre stosunki.

Dobiega końca także druk pracy Kotwicza o Józefie Kowalewskim, mongoliście, widzi więc Pan, że nasza orientalistyka nie próżnuje.

Składam Panu najserdeczniejsze podziękowania za cenny dar, chrestomatię języka tureckiego Dżewdeta ${ }^{75}$. Bardzo mi się przydała dla zajęć z moimi studentami I kursu języka tureckiego, ponieważ jest stosunkowo łatwa. W ostatnim czasie udało mi się nabyć dla mojej biblioteczki kilka cennych książek, przede wszystkim Słownik kumański Grønbecha ${ }^{76} \mathrm{i}$ inne prace turkologiczne.

Byłbym Panu bardzo wdzięczny, gdyby Pan mógł powiadomić prof. Gordlewskiego, że II tom „Rocznika Tatarskiego”, o który on prosi, jest nie do dostania, może on uprzejmie zgodzi się na zamianę na inne książki orientalistyczne wydane w Polsce (na przykład jakieś wydania Akademii, Mardkowicza, Grzegorzewskiego, Kowalskiego i in.). Mnie interesuje jego praca Gosudarstvo Sel'džukidov.

Paczki z książkami otrzymuję w całości i bez szwanku, a więc jeśli się uda dostać pracę prof. Gordlewskiego, będę bardzo zadowolony.

Często bywam u Marii Osipowny i Marianeczki. Marianna pracuje i uczy się, jeśli wszystko pójdzie dobrze, w przyszłym roku ukończy studia na uniwersytecie.

Serdeczne pozdrowienia proszę przekazać wielce szanownej Wierze Isakownej.

74 W. Zajączkowski, Resztki językowe Tatarów litewskich, SPAU 1948, t. XLIX, s. 396-400.

75 Hikmet Dżewdet-zade (1893-1945), urodzony w Stambule lingwista i historyk literatury. Lektor języka tureckiego w Leningradzkim Instytucie Wschodoznawstwa. Aresztowany w 1937 r. i represjonowany, w 1939 r. został zesłany do łagru w Kansku w Krasnojarskim kraju, gdzie kilka lat później zmarł. Oprócz wspomnianego tu wyboru tekstów pt. Hrestomatiâ tureckogo âzyka, wydanego w Leningradzie w 1931, był współautorem (z A.N. Kononowem) gramatyki współczesnego języka tureckiego (wyd. 1934).

76 Kaare Grønbech (1901-1957), duński turkolog i mongolista, od 1947 r. profesor Uniwersytetu w Kopenhadze. Tu mowa o jego pracy Komanisches Wörterbuch. Türkischer Wortindex zu Codex Cumanicus, wydanej w Kopenhadze w 1942 r. 


\author{
Całuję Pańskie ręce \\ i pozostaję szczerze oddany i szanujący Pana \\ Władimir
}

\title{
$\mathrm{Nr} 7$
}

Kraków 6 VII 1949

Wielce Szanowny Adonienu,

od dawna już zabieram się do napisania do Pana kilku słów, ale ciągle różne przeszkody uniemożliwiały mi realizację tego zamierzenia. W końcu znalazłem chwilę wolnego czasu, żeby napisać do Pana list.

Przede wszystkim spieszę podzielić się z Panem radosną dla mnie nowiną: po wieloletnich staraniach udało mi się osiągnąć stopień doktora filozofii w zakresie orientalistyki. Pracę doktorską napisałem na temat Turków-Gagauzów, szkic historyczno-etnograficzno-lingwistyczny. Zebrałem w niej wszystko, co zostało napisane o historii Gagauzów, a część etnograficzna stanowi próbę porównania wielu cech Gagauzów z folklorem ogólnotureckim. W części lingwistycznej omawiam dialekt Gagauzów i porównuję z anatolijsko-tureckimi dialektami Turcji. Głównym egzaminatorem był prof. Ananiasz Zajączkowski, który egzaminował mnie ze związków ludów tureckich z islamem, z tekstów XIV w. Burhaneddina koju, kroniki Aszyk pasza zade i Kysas ul-anbija. Prof. Kuryłowicz egzaminował z języka arabskiego i perskiego. Prof. Piwarski ${ }^{77}$ pytał z historii. W całości egzamin wypadł pomyślnie, tak że 28 VI odbyła się moja promocja doktorska. Promotorem był prof. Kuryłowicz.

W dniach 4-6 VI we Wrocławiu odbył się IX Zjazd Polskich Orientalistów, w którym wzięli udział wszyscy członkowie PTO. Na posiedzeniach naukowych przedstawiono 23 wykłady, których tematy obejmowały kraje od Chin do Afryki! Wybrano nowe władze Polskiego Towarzystwa Orientalistycznego: prof. A. Zajączkowski - prezes, ks. prof. A. Klawek - wiceprezes, dr Marian

77 Kazimierz Józef Piwarski (1903-1968), historyk, kierownik katedry Nowożytnej Historii Polski i Powszechnej UJ, w latach 1948-1950 dziekan Wydziału Humanistycznego UJ. 
Lewicki - sekretarz, dr Tadeusz Lewicki - skarbnik, członkowie Zarządu: prof. Kuryłowicz i prof. Jabłoński ${ }^{78}$.

Kończy się druk XV tomu „Rocznika Orientalistycznego” o objętości 480 stron. Odbitkę mojego artykułu o karaimskim senniku wysłałem do Pana przed paroma dniami. Oprócz „Rocznika” wychodzi „Przegląd Orientalistyczny”, 1 egzemplarz posłałem Panu.

W Komisji Orientalistycznej Polskiej Akademii Umiejętności drukuje się divan Ka'b ibn Zuhaira - stare arabskie poematy i studia na temat Šah-name śp. prof. Kowalskiego ${ }^{79}$.

Zastępcą na katedrze prof. Kowalskiego został dr Tadeusz Lewicki, który jesienią otrzymał stopień docenta. Także habilitacja Mariana Lewickiego już się załatwia, ale w Warszawie, w zakresie filologii mongolskiej. We Wrocławiu zacznie się niebawem druk Szkiców altajskich ${ }^{80}$ prof. Kotwicza. To bardzo ważna praca. W ogóle orientalistyka rozwija się.

Byłbym bardzo Panu zobowiązany za informacje, jakie przekłady utworów Puszkina znajdują się w materiałach bł. p. R. Józefa Łobanosa, dobrze było by wiedzieć, co w ogóle przełożył z literatury rosyjskiej.

Czy nie ma żadnej możliwości nabycia Gosudarstvo Sel'džukidov v Maloj Azii Gordlewskiego?

A poza tym drukowano kiedyś „Polski Biuletyn Orientalistyczny” t. I, czy nie można by gdzieś go odszukać? Mój ojciec z chęcią zgodzi się pokryć wszystkie wydatki.

Często bywam u Marii Osipowny i Marianny. Zawsze wspominamy Pana serdecznie. Także Maria Władysławowna Kotwicz, doktor Marian Lewicki, Władysław Zimnicki ${ }^{81}$ zawsze pytają o Pana. Pani Profesorowa Kowalska,

78 Witold Jabłoński (1901-1957), sinolog, historyk kultury i religioznawca, od $1947 \mathrm{r}$. kierownik Katedry Sinologii w Instytucie Orientalistycznym UW.

79 Chodzi o wydane pośmiertnie prace T. Kowalskiego: Le Dīwān de Ka’b ibn Zuhair. Édition critique T. Lewicki. (= Prace Komisji Orientalistycznej PAU nr 38), Kraków 1950 oraz Studia nad Šāh-nāme, t. I (= Prace Komisji Orientalistycznej PAU nr 39), Kraków 1952, t. II (= Prace Komisji Orientalistycznej PAU nr 40), Kraków 1953.

80 W. Kotwicz, Studia nad językami altajskimi, wydał M. Lewicki, RO 1951, t. XVI, s. 1-317.

81 Władysław Zimnicki (1897-1979), turkolog, lektor języka tureckiego na Uniwersytecie we Wrocławiu, od 1949 r. lektor-adiunkt, od 1951 r. docent w Instytucie Filologii Orientalnej UJ. 
Hanka i Kazik ${ }^{82}$ proszą przekazać Panu i Wierze Isakownie najserdeczniejsze pozdrowienia.

Całuję Pańskie ręce. Proszę przekazać moje wyrazy najgłębszej czci Wierze Isakownej.

Pozostaję oddany, głęboko szanujący Pana i życzący wiele zdrowia Władimir

\section{$\operatorname{Nr} 8$}

Kraków 1 X 1949

Wielce Szanowny Adonienu,

bardzo dziękuję Panu za list i serdeczne życzenia, które są dla mnie bardzo cenne. Zawsze marzyłem o pracy naukowej i obecnie moje pragnienia spełniają się, bowiem mam możliwość pracy w mojej ulubionej dziedzinie.

Napisałem prof. Ananiaszowi o Pańskim artykule, otrzymałem go z prośbą o odesłanie go Panu, bowiem trudno umieścić w jakimś czasopiśmie z powodu Pańskiej nieobecności. Dołączam więc do mego listu Pański rękopis.

Dziękuję Panu serdecznie za starania związane z kupieniem dla mnie książek. Prace prof. Millera udało mi się otrzymać i już napisałem o nich recenzję do „Kwartalnika Historycznego" ${ }^{33}$. Byłbym Panu niezwykle wdzięczny, gdyby udało się Panu dostać Gordlewskiego Gosudarstvo Sel'džukidov. Wydaje mi się, że prof. Gordlewskij poszukiwał „Rocznika Tatarskiego” t. II w zamian za swoją pracę. Jestem gotów wysłać mu swój egzemplarz „Rocznika Tatarskiego”, aby otrzymać „Seldżukidów”. Jeśli to jest niemożliwe, to może jest jakiś inny sposób?

82 Zofia Kowalska (1890-1975), wdowa po T. Kowalskim oraz jej dzieci: Anna Kowalska-Lewicka (1920-2009), etnograf, żona T. Lewickiego i Kazimierz Antoni Kowalski (1925-2007), zoolog, paleontolog, profesor UJ. Przed wojną kilkakrotnie odwiedzali Troki i Wilno.

83 Anatolij Filipowicz Miller (1901-1973), orientalista radziecki, autor prac z zakresu historii Turcji i Azji Centralnej oraz stosunków międzynarodowych na Bałkanach. W. Zajączkowski opublikował w „Kwartalniku Historycznym” 1949, nr 57, s. 274-275 recenzje prac Millera: Kratkaja istorija Turcii, wyd. 1948 oraz Očerki novejšej istorii Turcii, Moskwa - Leningrad 1948. 
Potrzebną Panu książkę Gumowskiego ${ }^{84}$ Numizmatyka litewska wysłałem na Pańskie nazwisko.

Niedługo będziemy rozsyłać XV t. „Rocznika Orientalistycznego”. Mam nadzieję, że otrzyma go Pan. Tom wygląda solidnie.

$\mathrm{U}$ nas życie toczy się normalnie. Profesorowa Kowalska z rodziną, Maria Osipowna z Marianną, Maria Władysławowna, dr Marian Lewicki, Władysław Zimnicki serdecznie Panu dziękują za pamięć i proszą o przekazanie Panu swoich serdecznych pozdrowień.

Całuję Pańskie ręce i Wiery Isakowny

Oddany i szczerze Pana szanujący

Władimir

\section{Nr 9}

Kraków 12 VI 1950

Wielce Szanowny Adonienu,

od dawna zabieram się do napisania listu do Pana, ale ciągle coś mi w tym przeszkadzało. Przede wszystkim proszę przyjąć moje serdeczne wyrazy wspólczucia z powodu śmierci Niezapomnianej i Wielce Czcigodnej Wiery Isakowny. Pamięć o niej pozostanie na zawsze żywa w naszych sercach.

Bardzo Panu dziękuję za pokonanie trudności związanych z wysyłaniem książek Tichomirowa Drevenerusskie goroda ${ }^{85}$ i Afanasija Nikitina Hoždenie za tri morâ ${ }^{86}$. Pierwszą książkę przekazałem profesorowi Mikuckiemu ${ }^{87}$, który

84 Marian Gumowski (1881-1974), historyk, numizmatyk, profesor UJ. Tu mowa o jego pracy Numizmatyka litewska wieków średnich: wykłady w semestrze letnim 1919. Nakł. Towarzystwa Numizmatycznego, Kraków 1920.

85 Chodzi o pierwsze wydanie Tihomirov, M.N., Drevenerusskie goroda, „Učënye zapiski Moskovskogo Gosudarstvennogo Universiteta im. M. V. Lomonosova”, nr 99, Moskwa 1946.

86 Relacja z podróży rosyjskiego kupca z Tweru, Afanasija Nikitina (zm. 1474/75) z podróży do Persji i Indii oraz drogi powrotnej, wzdłuż wybrzeża Afryki (Somali), przez Maskat i Turcję. Po raz pierwszy wydana drukiem w 1821 r., miała wiele wydań, nie jest jasne, o które $\mathrm{z}$ nich chodzi w tym wypadku.

87 Sylwiusz Mikucki (1898-1983), prawnik i historyk, kierownik Katedry Archiwistyki i Nauk Pomocniczych Historii UJ. Wydał Studia nad najdawniejsza dyplomatyka ruska, „Pamiętnik Słowiański” 1952, 3, s. 106-146. 
interesuje się średniowieczną historią Rusi. Bardzo się ucieszył. Nikitina Hożdenie udało mi się kupić w Warszawie, tak że mam 2 egzemplarze.

Przy okazji proszę o wybaczenie mi nowej śmiałości, ale już dłuższy czas szukam I t. pracy prof. N. A. Smirnowa Rossiâ i Turciâ $v$ XVI - XVII vv. wydanie Państwowego Uniwersytetu Moskiewskiego, Učenyje Zapiski vypusk 94, Moskva 1946. Byłbym Panu bardzo wdzięczny, jeśli mógłby Pan pomóc mi w zdobyciu I tomu tej pracy. II tom udało mi się przypadkowo otrzymać, ale bez I tomu praca traci całą wartość.

W dniach 27-29 maja odbył się w Warszawie X Zjazd Polskich Orientalistów. Pierwszy dzień był przeznaczony na wykłady o organizacji poszczególnych gałęzi orientalistyki (8 wykładów), a przez następne dwa dni wysłuchaliśmy 12 wykładów na tematy naukowe. W czasie Zjazdu zwiedziliśmy Wystawę Książki Orientalnej i chińskiej drewnianej ksylografii. Zobaczyliśmy wiele interesujących przedmiotów. Ogólnie nastrój był bardzo dobry i Zjazd udał się całkowicie.

Jednocześnie posyłam Panu odbitki ostatnich moich artykułów, między innymi o tureckich pisarzach ${ }^{88} \mathrm{z}$ nowego numeru „Przeglądu Orientalistycznego”, który ukazał się podczas Zjazdu.

U mnie wszystko w porządku. Pracuję jak dawniej. Drukuje się praca śp. prof. Kowalskiego „Šah-name”.

Czy mógłby Pan mi przysłać spis utworów rosyjskich poetów przetłumaczonych na język karaimski przez bł. p. J. Łobanosa? Chciałbym napisać artykuł na temat: karaimskie przekłady literatury rosyjskiej.

Pozostaję głęboko Pana szanujący

Całuję mocno Pańskie ręce

Oddany

Władimir

\section{Nr 10}

Kraków 23 II 1958

Wielce Szanowny Adonienu,

Proszę mi wybaczyć, że niepokoję Pana, ale nie mając innego wyjścia, zdecydowałem się zwrócić do Pana. Otrzymałem pewną ilość pieśni z Krymu,

88 W. Zajączkowski, Prozaicy nowej Turcji, PO 1950, nr 2, s. 67-72. 
które chciałbym wydaćs9 , ale napotkałem wiele niezrozumiałych dla mnie słów, o wyjaśnienie których bardzo proszę. Oto spis tych słów: ${ }^{90}$

$1{ }^{91}$ nè tûjû kalyr ne bakla.

2. tir'âki olmuš bu syčan.

3. ânyčar aga ona tahryk

4. azbarymda kok tana

5. èlimde altyn kogum.

6. anavu kyrnyn [1] appidžan

[2] čippiim.

7. gozčikleryn humry gozy.

8. salačyk dedykleri

9. ûzu gozy syrdan dilil

10. ort' jazmany bojdan boûnčes.

11. ben aramadym sarysyn el'ler doûnčas.

12. šu erler sizyn ola. dyregi ûzun ola

13. Aj balam, balam, balam, odaman balam.

14. humry gozli, ûmran bašly,

15. togerek ûzli, čygyryk gozli

16. kana sutli, âlpu betli.

17. ûmrï ûvalak. čak âlpak.

18. Akmedžitnyn kyzlary byr byrinden orteke

19. Eski-kyrymmnyn kyzlary pahynlyktan kan sier.

20. Èj analyk analyk. [dopisek S. Szapszała ołówkiem:] Oj matuški, matuški! ['oj, mateczki, mateczki!']

21. Aladža fistan al balakta.

22. Istanbolnyn kyzlary byri byrinden suvuruk baš.

23. Karasuvnun kyzlary byri byrini jaqtïra.

24. byr oluqsyz oguz dyr. [dopisek S. Szapszała ołówkiem:] Byk bez odnogo stojla ['byk bez jednej zagrody']

25. Jerde bitken koguz dir. [dopisek S. Szapszała ołówkiem]: Koguz? rastuŝij na zemle ['Koguz? rosnący na ziemi'] [z3] varyloč.

89 Był to rękopiśmienny zbiór pieśni przekazany przez E. Bezekowicza, z pochodzenia Karaima trockiego. W. Zajączkowski opublikował je w „Roczniku Orientalistycznym” (Z poezji ludowej tatarsko-karaimskiej na Krymie, RO 1961, t. XXIV, z. 2, s. 119-147).

90 W oryginale listu zapisano je cyrylicą. W niniejszej edycji zastosowano transliterację według standardu przyjętego przez Państwowe Wydawnictwo Naukowe. Zob. http://sjp.pwn.pl/zasady/307-76-A-Transliteracja-wspolczesnego-alfabeturosyjskiego;629696.html [Dostęp: 06.12.2016].

91 Numeracja dopisana ołówkiem przez S. Szapszała. 
26. akar solaknynn baly.

27. kogurčin tabuhly dostym

dympyłdaj. [dopisek S. Szapszała ołówkiem:] pripev posle pesni ['refren po piosence']

28. azmaq ile tèzmek ile

29. alkan direm kazma ile

30. uzundur sebynyn daly [między wersami dopisek S. Szapszała ołówkiem:] sel'binin [dopisek S. Szapszała ołówkiem:] dlinnâ stebel' topol'â ['długi pień topoli']

32. ešitmez kyzlaryn èli [nad $\check{s}$ w wyrazie ešitmez poprawka S. Szapszała ołówkiem:] $t$

31. top-top olyp kelyr kyzlar.

32. tûšinmeden sioz berdym ajgidy âšlyk.

33. tèrèn kuûga taš atsam čyngyrdaj kètèr. [poniżej dopisek S. ołówkiem]: Esli v glubokij kolodec â brošu kamen', to po[nieczytelne]t s tresk[om?] ['jeśli do głębokiej studni wrzucę kamień, [poleci?] z grzechot[em]']

354. opsem humrular gibi

365. bir gemym var ben koj verdym ankine-ankine

37. bazirganlar toškaj urar dankine,

38. èm hafislik èm kurbetlik

39. ne hoš olur aman asistannyn ušagy

40. karylgač kajda varasyn, kanatynman er sazyp.

41. ak kaftanym yrmasy, bojnyn burup durmačy

42. ben garyby âkmačy.

43. čykkaj idy gozleryn jarmy goredžek.

44. âr uûdan uânmyš gozlery mahmur [podkreślenie S. Szapszała ołówkiem]

45. benim byr èfendym var ûzleri samur [podkreślenie S. Szapszała ołówkiem]

46. koktè taparlandy dahnyn dumany.

47. apakajga arpa èkmek, kyzlara inžyr.

48. talak olup ketè-èkèn âlan dun'â.

Będę Panu bardzo wdzięczny jeśli znajdzie Pan czas na objaśnienie wszystkich tych wypisanych przeze mnie zdań i poszczególnych wyrażeń.

Tylko Pan jest jedynym człowiekiem, który może mi pomóc, ponieważ nie ma już specjalistów od języka krymskiego. [Passus zakreślony przez S. Szapszała ołówkiem na marginesie]

Moje życie toczy się normalnie. Pracuję jak do tej pory. Od 24 IX do 9 XI byłem w Bułgarii, gdzie badałem we wsiach gagauzkich ich język i życie.

W Warnie spotkałem się z rodziną Kalfa. Prosili, by przekazać Panu serdeczne pozdrowienia. Pan Kalfa choruje na serce, nie wychodzi z domu. Jego małżonka pracuje jako lekarz. Ich córka, Dina, jest już dorosła, ukończyła 
wyższe studia, jest inżynierem chemikiem. Wyszła za mąż za pułkownika armii bułgarskiej, który wykłada w Wyższej Akademii Wojskowej w Sofii.

Marianna Abrahamowicz przebywa na stypendium w Londynie, gdzie doskonali znajomość języka angielskiego i literatury. Maria Osipowna zajmuje się wychowaniem wnuka ${ }^{92}$. W rodzinie prof. Kowalskiego także wszystko dobrze.

Niecierpliwie będę czekał na odpowiedź.

Bardzo Panu dziękuję i przepraszam.

Ręce Pańskie całuję i proszę o Pańskie błogosławieństwo

Serdecznie oddany

Władimir

\section{Nr II}

[Kartka pocztowa]

Warna 28 X 1958

Przesyłam serdeczne pozdrowienia ze słowami prawdziwego szacunku z Bułgarii, gdzie badam język i folklor Gagauzów.

Bardzo dziękuję za list i wyjaśnienie krymskich słów.

Z głębokim poważaniem

W. Zajączkowski

\section{Bibliografia}

$\mathrm{PO}=$ Przegląd Orientalistyczny

PSB = Polski Słownik Biograficzny

RO = Rocznik Orientalistyczny

SPAU = Sprawozdania z posiedzeń i czynności Polskiej Akademii Umiejętności

Abkowicz, M., Sulimowicz, A., Karaj jołłary - Karaimskie drogi. Karaimi $w$ dawnej fotografii, Wrocław 2010.

Abkowicz, M., Karaimskie życie spoleczne w Polsce po 1945 roku, [w:] Machul-Telus B., Karaimi, Warszawa 2012, s. 180-205.

92 Michał (ur. 1953), syn Marianny i Zygmunta Abrahamowiczów. 
Biogramy uczonych polskich. Materiały o życiu i działalności członków AU w Krakowie, TNW, PAU, PAN. Cz. I. Nauki społeczne. Zeszyt 3. Opracowali Śródka A., Szczawiński P., Wrocław 1985, s. 94-97.

Dubiński, A., Prof. Dr. Włodzimierz Zajaczkowski, On the occasion of his $65^{\text {th }}$ birthday. Bibliography of the works of Włodzimierz Zajaczkowski, „Ural-Altaische Jahrbücher” 1981, Neue Folge, t. 1, s. 255-269.

Dubiński, A., Włodzimierz Zajaczkowski in memoriam, PO 1983, 1-4 (125-128) s. 183-185.

Dubiński, A., Szymona Firkowicza twórczość literacka w jezyku karaimskim, PO 1993, 3-4 (167-168), s. 204-210.

Grzybek, S., Śp. ks. prof. Aleksy Klawek (1890-1969), „Ruch Biblijny” 1970, 23, s. 263.

Godzińska, M., Włodzimierz Zajączkowski - badacz folkloru ludów tureckich, „Almanach Karaimski” 2014, nr. 3, s. 37-40.

Górski, T., Nekrolog [A. Klawek], „Życie i Myśl” 1970, nr 4, s. 147-148.

Kałużyński, S., Marian Lewicki (15 VIII 1908 - 13 XI 1955), PO 1956, nr 3 (19), s. 299-312.

Kałużyński, S., Władysław Kotwicz na stulecie urodzin, PO 1972, nr 2 (82), s. 103-114.

Kałużyński, S., Marian Lewicki (na 25-lecie śmierci), PO 1980, nr 4 (116), s. 364-366.

Kozłowska M., przy współpracy J. Tulisowa, Katalog ksiegozbioru Profesora Władysława Kotwicza. Cz. 1. Numery inwentarzowe 1-800, „Collectanea Orientalia”, 3 (19), Warszawa 2015.

Lewicki, M., Władysław Kotwicz (20.II.1872-3.X.1944), RO 1953, 16, s. XI-XXIX.

Listy Ananiasza Zajaczkowskiego do Seraji Szapszała, „Almanach Karaimski” 2013, nr 2, s. 65-163.

Łoza, S. (red.), Czy wiesz kto to jest?, Warszawa 1938 (reprint 1984).

Majda, T. (red), Urzeczeni Orientem. Listy Ananiasza Zajaczkowskiego do Tadeusza Kowalskiego, Warszawa 2013.

Majda, T., Ananiasz Zajaczkowski 1903-1970, [w:] Baraniewski W., Tygielski W., Wróblewski A. K. (red.), Portrety Uczonych. Profesorowie Uniwersytetu Warszawskiego po 1945, Warszawa 2016, s. 536-547.

Niekricz, A., Mądrość i dobro świata, „Awazymyz” 2012, nr 1 (34), s. 14-15.

Pawelec, M., Seraja Szapszal i jego wkład w polską orientalistyke, „Awazymyz” 2012, nr 1(34), s. 4-8.

Pawelec, M., Niezapomniane spotkania, tamże, s. 9-10.

Pawelec, M., Listy do Wilna. Seraja Szapszat jako korespondent Ananiasza Zajaczkowskiego, „Almanach Karaimski” 2013, nr 2, s. 19-36.

Pilecki, S., Chłopiec z Leśnik. Dziennik lat 1939-1945, Wrocław 2009.

Pilecki, S., Karaimskie życie rodzinne, społeczne i religijne okresu międzywojennego, [w:] Machul-Telus B. (red.), Karaimi, Warszawa 2012, s. 34-52.

Prohorov, A. M. (red.), Sovetskij Ėnciklopedičeskij Slovar', wyd. IV, Moskva 1987.

Siemieniec-Gołaś, E., Tadeusz Kowalski (1889-1948), „Studia Turcologica Cracoviensia” 1998, t. 5, s. 91-111.

Siemieniec-Gołaś, E., Włodzimierz Zajączkowski (1914-1982), [w:] Złota Księga Wydziału Filologicznego, Michalik, J., Walecki, W. (red.), Kraków 2000, s. 673-675.

Smoczyński, W. (red.), Kuryłowicz Memorial Volume, Part One, Kraków 1995. 
Sulimowicz, A., Polscy turkolodzy Karaimi. Od przedmiotu do podmiotu badań naukowych, [w:] Machul-Telus B. (red.), Karaimi, Warszawa 2012, s. 136-140.

Sulimowicz, A., Listy do Eucka. Aleksander Mardkowicz jako adresat korespondencji Ananiasza Zajaczkowskiego, „Almanach Karaimski” 2013, t. 2, s. 37-60.

Sulimowicz, A., Działalność społeczna i edukacyjna Koła Pań Karaimskich w Haliczu, „Almanach Karaimski” 2015, t. 4, s. 79-100.

Tadeusz Kowalski 1889-1948. Materiały z Posiedzenia Naukowego PAU w dniu 19 czerwca 1998 r., „W służbie nauki” 1999, 4, Kraków 1999.

Tryjarski, E., Studia turkologiczne Władysława Kotwicza (1872-1944), „Nauka Polska” 1973, nr 2, s. 139-145.

Tryjarski, E., Eugeniusz Słuszkiewicz - najwybitniejszy armenista polski(1901-1981), PO 1983, nr 1-4, s. 11-19.

Tryjarski, E., O Profesorze Włodzimierzu Zajączkowskim i wspólnej z nim podróży do Jerozolimy, PO 2001, nr 3-4 (198-199), s. 260-265.

Tryjarski, E., Restoration of Oriental Studies in Poland after the World War II as Reflected in Five Letters by Tadeusz Kowalski, „Studia Turcologica Cracoviensia” 1998, nr 5, s. 267-285.

Tulisow, J., Władysław Kotwicz, „Hemispheres” 1986, 2, s. 199-215.

Tulisow, J. (red.), In the heart of Mongolia. 10oth Anniversary of W. Kotwicz's Expedition to Mongolia in 1912, Kraków 2012.

Tyszkiewicz, J., Początki seminarium turkologicznego prof. Ananiasza Zajaczkowskiego: 1933-1936, „Almanach Karaimski” 2014, t. 3, s. 107-118.

Wróblewska, U., Działalność kulturalno-oświatowa Karaimów w Drugiej Rzeczypospolitej, Białystok 2015.

Zajączkowska-Łopatto, M. E., Działalność zawodowa i społeczna Karaimów trockich $w$ Warszawie w XX wieku, [w:] Bairašauskaite, T., Kobeckaitè, H., Miškinienė G. (red.), Orientas Lietuvos Didžiosios Kunigaikątijos visuomenés tradicijoje: Tototriai ir Karaimai. Orient in the social tradiction of the Grand Duchy of Lithuania: Tatars and Karaims. Orient $w$ tradycji społeczeństwa Wielkiego Ksiestwa Litewskiego: Tatarzy i Karaimi, Wilno 2008, s. 299-309.

Zajączkowska-Łopatto, M. E., Obowiązek i ofiara. Życie i działalność mecenasa Izaaka Zajaczkowskiego, „Awazymyz” 2015, nr 1 (46), s. 4-8.

Zajączkowski, A., Tadeusz Kowalski i jego prace orientalistyczne (21 VI 1889 - 5 V 1948), [w:] Ksiega dla uczczenia pamięci Tadeusza Kowalskiego (1889-1948), RO 1951-1952, t. 17, s. IX-XVI.

Zajączkowski, A., Wspomnienie o Marianie Lewickim, PO 1956, nr 3 (19), s. 291-298.

Zajączkowski, A., Kotwicz, Władysław, PSB, 1969, t. 14, s. 507-50.

Zajączkowski, W., Wspomnienie pośmiertne o prof. Władysławie Kotwiczu, „Prawda Wileńska” 15 X 1944, s. 5.

Zajączkowski, W., Bibliografia Tadeusza Kowalskiego, [w:] Księga dla uczczenia pamięci Tadeusza Kowalskiego (1889-1948), RO 1951-1952, t. 17, s. XVII-XXXVI.

Zajączkowski, W., Pamięci wybitnego orientalisty [M. Lewickiego], „Tygodnik Powszechny” 1956, nr 1 (544), s. 2. 
Zajączkowski, W., Prof. dr Tadeusz Lewicki, PO 1971, nr 77, s. 101-102.

Zajączkowski, W., Bibliographie des travaux de Tadeusz Lewicki, „Folia Orientalia” 1970, t. 11, s. $7-47$.

Zajączkowski, W., Maria Kotwicz (1897-1978), PO 1978, nr 3 (107), s. 30.

Zajączkowski, W., Władysław Zimnicki(1897-1979), „Folia Orientalia” 1979, t. 20, s. 315-316. 
